\title{
Internal Causes of Financial Fragility and System Lack in West African Countries
}

\author{
-Take Congo(B) for Example \\ YING Yi-rong ${ }^{1,}$, , Ossou Ndzila, Fred Nelson ${ }^{1}$ \\ ${ }^{1}$ College of Economics, Shanghai University, shanghai,200444, China \\ aemail:yrying@staff.shu.edu.cn
}

Keywords: financial fragility, currency crisis, financial stability, financial liberalization

Abstract. In this paper, we take the Republic of Congo for Example, and discuss the internal causes of financial fragility and system lack in West African countries. At last, we put forward some suggestions for the Republic of Congo to avoid financial fragility in the future.

\section{Introduction}

Introduction In 2007, the subprime loans crisis of the United States had swept the whole world. Currently, the suggestion of changing the current international monetary system has been put forward. Under this situation, the study about financial stability of emerging market countries like west Africa has important practical significance. In theory, the academic for the emerging markets crisis has long been discussed many related and forma more mature model of three generations of the finance crisis. Krugman (1979) who put forward the "model of rational attracks" explained the currency crisis during 1970-1980s well; Obstfeld (1995) perfected second generation currency crisis model based on normative and policy option, and he successful represented the outbreak of the 1992-1993 crisis in European monetary system and Mexican peso crisis during 1994-1995; Krugman (1996) has set up the finance system instability model to explain the Asian financial crisis during 1997-1998.

\section{Financial Fragility in West Africa Countries}

In the subprime loans crisis of the United States, some West Africa countries have been affected to varying degrees, their security markets and foreign exchange markets shocks at one time. If we overview of the whole capital account liberation process, the most countries in the world went through the 1950-1960 era of capital regulation, the 1970-1980 era of relaxed capital control, as well as universal era of accelerated capital account since 1990s. The financial liberalization appeared in the U.S. in the 1980s, and spread to other developed countries in the last three decades. Since the end of 1990 s, the acceleration of financial globalization and subsequent crises has aroused scholarly interests in the phenomenon of "financialization"(Krippner2005; Froud and Johal2006; Lucarelli2012; Der Zwan2014;). For most studies of financialization, definition and measurement may be very different, but object refers to private financial sectors. For example, Greta Krippner's flagship research in this field measures financialization as both the growth of financial sector profits and the growing reliance of nonfinancial firms on financial activities in economies (Davis and Kim2015; Riaz2016). The current literature has started to consider the government as an object of financialization. Governments have invariably been portrayed as suppliers of regulation (and deregulation) policies who facilitate the financialization of economies (Davis and Kim2015). Little attention has been paid to how government themselves can be institutional investors in the financial market and how such mutations will change the way governments manage budgets and finance public investment. Most of existing literatures on financialization incorrectly presume that the state and the market can be neatly separated and usually focus on case studies of liberalized and developed economies (Goyer2006; Correa, Vidal, Marshall, et al 2012). Few researches have investigated less liberalized and developing ones. There is a real need to understand the role of the government in the development of financial markets and 
provision of financial products (Akkemik and Ozen2014). In this regard, the world's second largest economy China presents a special case in which financialization has become a growing method for the public finance of the local governments.

Not only the finance markets are backward, but also the difference between the health financing needs and the available resources for health are huge in developing countries including in Sub-Saharan Africa. Developing countries account for $84 \%$ of the world's population, $90 \%$ of the global disease burden but only $12 \%$ of global health spending. Of the $12 \%$ global health spending by developing countries, the share of low-income countries including those in Sub-Saharan Africa is only $2 \%$.

Of course, nor is it good for nothing. A different alternative for health financing which is increasingly becoming prevalent in Sub-Saharan African countries is CBHI. Theoretically, CBHI seems to be a workable option for health financing and risk protection of rural households in Sub-Saharan countries. It is safe to assume that the challenges associated with other health financing options gave rise to the popularity of CBHI. Insurance is a mechanism of deferring risk in exchange for payment of a premium. Insurance plays an important role in achieving universal health care coverage particularly in countries where government is not able to raise adequate tax revenue to provide health services for all.

There is a place we shall pay much attention to, CBHI schemes are more prevalent in West African countries, among which; Senegal, Guinea, Burkina Faso, Mali, Benin, Cameron, Ivory Coast, Niger, Chad and Togo lead the pack in terms of number of CBHI schemes. Data from 11 West African countries shows that, the number of community health insurance schemes has shown an incredible growth from 76 schemes in 1997 to 366 in 2003 and 626 in 2006.

\section{Trade of The Republic of Congo}

In general, the financial crisis usually relied on the overflow of trade and financial spillovers, the net transmission of blast effects and transmission effects. We shall pay much attention on two fronts about the crisis transmission mechanism and conduction mechanism to finance markets in the West Africa countries. From internal conditions in these countries, there exists endogenous vulnerability in their financial system, such as currency volatility, the volatility of financial asset prices, the lack of maturity of the prevalence of effective market mechanisms. In addition, financial markets, policy makers are also policy instruments regulating the economy through the development of an important channel for policy-making led to changes in the financial system and the possible uncertainty in the external market.

Table1(a) Trade of The Republic of Congo in $2014 \quad$ unit: billion XAF

\begin{tabular}{ccccccc}
\hline Trade & Jan. & Feb. & Mar. & Apr. & May. & Jun. \\
\hline import & 1895.1 & 69.6 & 1415.2 & 1545.1 & 2906.0 & 3921.9 \\
export & 1180.0 & 1356.7 & 1166.7 & 1287.8 & 1027.8 & 1181.2 \\
Total & 3075.1 & 1426.3 & 2581.9 & 2832.8 & 2906.8 & 5103.1 \\
\hline \multicolumn{2}{l}{ Resource: From Custom } & Statistic of The Republic of Congo. & 1 dollar=500XAF
\end{tabular}

Table 1 (a) and Table 1(b) shown us, the fluctuation of trade volume of the Republic of Congo is quite large. For example, the trade volume in June is about 90 times high than that in October.

Table1(b) Trade of The Republic of Congo in $2014 \quad$ unit: billion XAF

\begin{tabular}{lllllll}
\hline Trade & Jan. & Feb. & Mar. & Apr. & May. & Jun. \\
\hline import & 1895.1 & 69.6 & 1415.2 & 1545.1 & 2906.0 & 3921.9 \\
export & 1180.0 & 1356.7 & 1166.7 & 1287.8 & 1027.8 & 1181.2 \\
Total & 3075.1 & 1426.3 & 2581.9 & 2832.8 & 2906.8 & 5103.1 \\
\hline
\end{tabular}

Resource: From Custom Statistic of The Republic of Congo. 
However, the trade volume in September suddenly drops from 485 billion XAF to 6 billion XAF in the next month, the drop rate is as high as $90 \%$, out of our expectation, the trade volume in November rises to 343 billion XAF, and it suddenly drops again, from 343 billion XAF to 9 billion $\mathrm{XAF}$, it just like a roller coaster! This sharp fluctuation more or less reflects one side of finance fragility of Congo (B).

Table 2 Export of The Republic of Congo

unit: billion XAF

\begin{tabular}{ccc}
\hline Trade & Total Volume & Percentage (\%) \\
\hline China & 13132 & 55.13 \\
Australia & 9106 & 12.21 \\
Italy & 1678 & 7.04 \\
France & 1172 & 4.92 \\
Portugal & 912 & 3.83 \\
Total & 19808 & 83.13 \\
\hline
\end{tabular}

Resource: From Custom Statistic of The Republic of Congo. 1 dollar=500XAF

Starting from 1982, China began to take up workforce contracts and has achieved better results. The trade between China and the Republic of Congo has witnessed a quicker development in recent years and from 2001, China started to import crude oil directly from the Congo. The year of $2005 \mathrm{saw}$ the trade value of the two countries reach US $\$ 2.423$ billion, of which the Chinese export took up US\$145 million while the import was US\$2.278 billion. The impact of imports from China is remarkable since the imported goods contribute in economizing the resources and therefore leads to benefits at the external trade level of Congo. From table 2 one can see that China take advantage of export of the Republic of Congo, she accounts for half of total export volume of The Republic of Congo (table 2). In the aspect of import, China and France are so well-matched that neither could gain the upper hand, each country accounts for one sixth of total import volume of The Republic of Congo (table 3).

Table 3 Import of The Republic of Congo unit: billion XAF

\begin{tabular}{ccc}
\hline Trade & Total Volume & Percentage (\%) \\
\hline China & 2849 & 17.52 \\
France & 2824 & 17.24 \\
Beligim & 2027 & 12.46 \\
Italy & 942 & 5.79 \\
United States & 802 & 4.93 \\
Total & 9424 & 57.94 \\
\hline
\end{tabular}

Resource: From Custom Statistic of The Republic of Congo. 1 dollar=500XAF

\section{Conclusions}

In the light of the above discussion about the internal causes of financial fragility and lack of system in Congo (B), in the new situation of China-Africa economic relations development, Congo (B) can promote the development of economic cooperation. Therefore, we suggest: First, strengthen bilateral cooperation. By means of the joint efforts of both sides, the two sides finally achieve mutual benefit and win-win situation. Ever since the establishment of the diplomatic relations China provided Congo (B) with some economic aids, undertaking such sets of projects as stadium, broadcasting station, assembly building, textile mill, hospital and hydropower station construction. Second, improve the regulatory system. The new challenge is on effective management of vital monetary resources generated by exporting natural resources to China. At last, strengthen institutional mechanism and improving the macroeconomic environment. Chinese companies, especially those in 
the forest sector, should be well controlled and the legislation requiring that most of the undressed timber be transformed at source should be fully enforced. Raw material exports, particularly crude oil to China have generated significant monetary reserves that the country should benefit from to diversify its economy.

We explore internal causes of financial fragility and system lack, our aim is to to optimize the investment effective between China and Congo (B), and promote the development of economic cooperation in the issue of macroeconomic risks and micro-factors from the perspective of micro-point of view. Our analysis can help to solve the obstacles on the road of economic cooperation between China and Congo (B).

\section{Acknowledgements}

This work was financially supported by the National Natural Science Foundation of China under Grant No. 71171128

\section{References}

[1] B. Lucarelli. Financialization and Global Imbalances: Prelude to Crisis. Review of Radical Political Economics Vol44 (2012), p.429-447.

[2] E. Correa, G. Vidal, W. Marshall, et al. Financialization in Mexico: trajectory and limits. Journal of Post Keynesian Economics Vol35 (2012), p.255-275.

[3] G R. Krippner. The financialization of the American economy. Socio-economic Review Vol3 (2005), p. 173-208.

[4] G F. Davis and S. Kim Financialization of the Economy. Review of Sociology Vol41 (2015), p, 203-221.

[5] J. Froud and S. Johal, A. Leaver and K.Williams. Financialization and Strategy: Narrative and Numbers. Routledge. (2006)

[6] K A. Akkemik and Ş. Ozen. Macroeconomic and institutional determinants of financialisation of non-financial firms: Case study of Turkey. Socio-economic Review Vol 12 (2014), p.71-98.

[7] M. Goyer. Varieties of Institutional Investors and National Models of Capitalism: The Transformation of Corporate Governance in France and Germany. Politics \& Society Vol34, (2006), p.399-430.

[8] M. Obstfeld, K. Rogoff. The Mirage of Fixed Exchange Rates. Journal of Economic Perspectives Vol9 (1995),p. 73-96.

[9] N. V. Der Zwan Making sense of financialization. Socio-economic Review Vol12, (2014), p. 99-129.

[10] P. Krugman. A. Model of Balance-of-Payment Crises. Journal of Money, Credit and Banking, Issue(11) (1979), P. p.311-325.

[11] P. Krugman, R.Flood, P. Garber Charles Kramer. Collapsing Exchange Rate Regimes: Another Linear Example. Journal of International Economics Vol41 (1996), p.223-234.

[12] S. Riaz Debt et al. Towards a Critical Examination of Organizational Roles in Debt Practices and Financialization. The Routledge Companion to Philosophy in Organization Studies. (2016) 